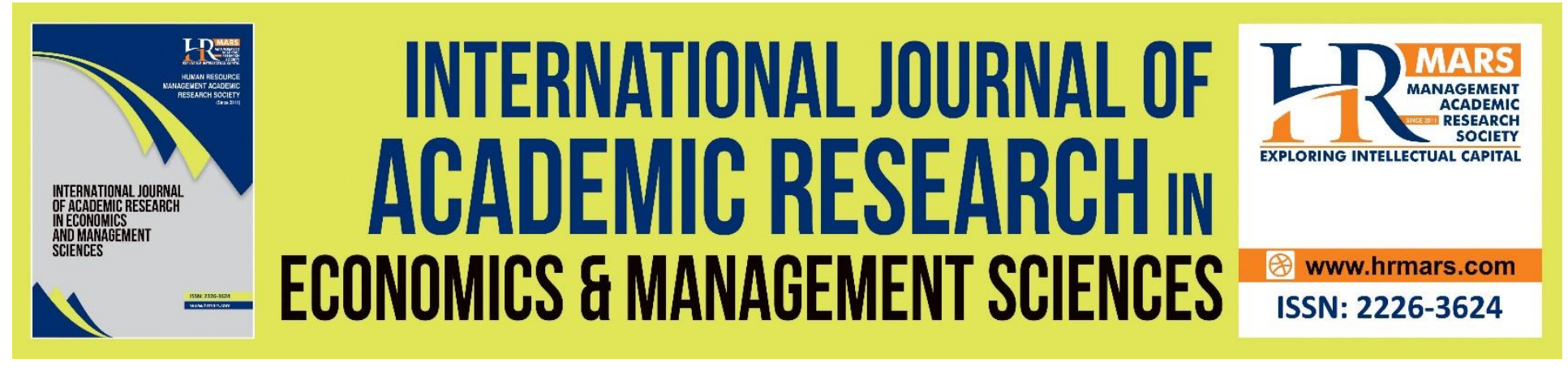

\title{
A Study of Relationships between Social Media Marketing, EWOM and Brand Loyalty towards Repurchase Intention of Smartphones in China
}

Bai Jiayu, Wong Chee Hoo, Tan Seng Teck, Liew Cheng Siang, Yip Foon Yee

To Link this Article: http://dx.doi.org/10.6007/IJAREMS/v10-i4/11625 DOI:10.6007/IJAREMS/v10-i4/11625

Received: 28 September 2021, Revised: 25 October 2021, Accepted: 06 November 2021

Published Online: 24 November 2021

In-Text Citation: (Jiayu et al., 2021)

To Cite this Article: Jiayu, B., Hoo, W. C., Teck, T. S., Siang, L. C., \& Yee, Y. F. (2021). A Study of Relationships between Social Media Marketing, EWOM and Brand Loyalty towards Repurchase Intention of Smartphones in China. International Journal of Academic Research in Economics and Management and Sciences, 10(4), 18-30.

Copyright: (c) 2021 The Author(s)

Published by Human Resource Management Academic Research Society (www.hrmars.com)

This article is published under the Creative Commons Attribution (CC BY 4.0) license. Anyone may reproduce, distribute, translate and create derivative works of this article (for both commercial and non-commercial purposes), subject to full attribution to the original publication and authors. The full terms of this license may be seen at: $\underline{\text { http://creativecommons.org/licences/by/4.0/legalcode }}$

Vol. 10, No. 4, 2021, Pg. 18 - 30

http://hrmars.com/index.php/pages/detail/IJAREMS

JOURNAL HOMEPAGE

Full Terms \& Conditions of access and use can be found at http://hrmars.com/index.php/pages/detail/publication-ethics 


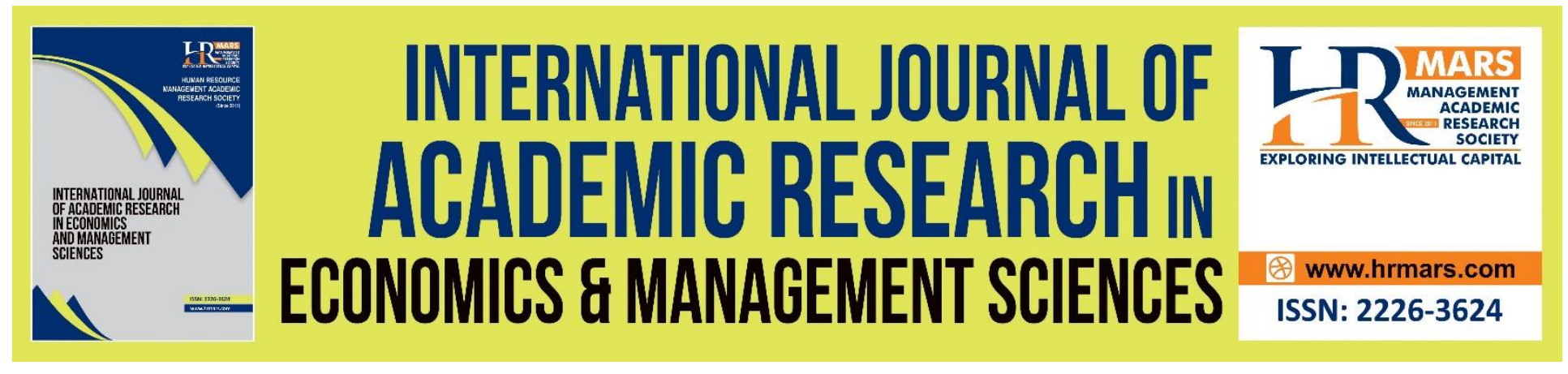

\title{
A Study of Relationships between Social Media Marketing, EWOM and Brand Loyalty towards Repurchase Intention of Smartphones in China.
}

\author{
Bai Jiayu ${ }^{1}$, Wong Chee $\mathrm{Hoo}^{2}$, Tan Seng Teck ${ }^{3}$, Liew Cheng \\ Siang ${ }^{4}$, Yip Foon Yee ${ }^{2}$ \\ ${ }^{1}$ Postgraduate Student, INTI International University, Malaysia, ${ }^{2}$ Senior Lecturer, INTI \\ International University, Malaysia, ${ }^{3}$ Associate Professor, INTI International University, Malaysia \\ ${ }^{4}$ Dean, Faculty of Business, Communication and Law, INTI International University, Malaysia. \\ Corresponding Author: cheehoo.wong@newinti.edu.my
}

\begin{abstract}
As with the growth of social media marketing, conventional marketing tactics have increasingly been abandoned, and customer purchasing behaviours have transformed as well. Social media marketing techniques are founded on social media platforms where consumers actively seek information about a product or service and the opinions of other consumers before making a purchasing decision. The sharing of brands, product reviews, and user experiences is a component of e-WOM, or electronic word of mouth, in which information is transmitted and received via the Internet. Electronic word-of-mouth and social media marketing will have an effect on brand loyalty and, eventually, on consumers' purchase intentions. The purpose of this study is to examine the impact of social media marketing, brand loyalty, and electronic word-ofmouth on customers' purchase intentions, using the purchase of a mobile smart phone as an example. 200 questionnaires will be collected in Guangzhou at the conclusion of the study. Five alternative theories are advanced and examined. The findings indicate that social media marketing, brand loyalty, and electronic word of mouth all have a significant impact on customer behaviours that result in buy or repurchase intentions. These findings imply that social media marketing should place a premium on positive word of mouth, generating a favourable impression, and promoting consumer involvement in order to foster brand loyalty.

Keywords: Social Media Marketing, EWOM, Brand Loyalty, Repurchase Intention, Smartphones in China.

\section{Background of the Research}

By June 2020, China's Internet population would have surpassed 940 million, accounting for onefifth of the world's Internet population. Internet penetration reached 67 percent, approximately five percentage points higher than the global average. The percentage of Internet users who
\end{abstract}


utilise cell phones is 99.2 percent. As of March 2020, netizens aged 20 to 29 and 30 to 39 account up 21.5 percent and 20.8 percent of the total population, respectively, significantly higher than the other age groups. Internet users between the ages of 40 and 49 made up 17.6 percent of the total; Internet users beyond the age of 50 made up 16.9 percent of the total, indicating that the Internet has penetrated the middle and upper age classes. As of March 2020, netizens with junior middle school, high school, technical secondary school, or technical school education accounted for 41.1 percent, 22.2 percent, and 19.5 percent, respectively, in terms of education, while netizens with or above college education accounted for 19.5 percent. In terms of revenue, netizens earning between 2,001 and 5,000 yuan (RMB, see below) make up 33.4 percent, 27.6 percent of those earning more than 5,000 yuan, and 20.8 percent of those earning less than 1,000 yuan. Additionally, the survey indicated that China had 496 million non-Internet users during the same period, with the majority of non-Internet users remaining in rural areas. The primary causes for non-Internet use are a lack of skills, a low level of education, and age.

\section{Problem Statement}

Numerous factors influence consumers' purchasing decisions. To conduct a more detailed analysis of the relevant components, we can first examine consumers' purchasing intentions. On July 23, the cloud-based 19th China Internet Conference began with the publishing of the China Internet Development Report 2020. According to the research, China's mobile Internet users hit 1.319 billion by the end of 2019, accounting for 32.17 percent of the world's total Internet users. The overall number of $4 \mathrm{G}$ base stations worldwide has increased to 5.44 million, accounting for more than half of all $4 \mathrm{G}$ base stations. The number of e-commerce transactions totals 34.81 trillion yuan, cementing China's leadership in the global e-commerce business for several years. Online payment transactions were 249.88 trillion yuan, and China led the globe in mobile payment penetration. China's economic added value from digital technologies reached 35.8 trillion yuan, placing second globally. The rapid growth of e-commerce in China has also created a slew of complications.

The Chinese market is saturated with mobile smart phone brands. Whether it is a home brand like Huawei or a foreign brand like Apple or Samsung, they all have a sizable loyal fan base in China's massive mobile smart phone consumer market. For many people who acquire mobile smart phones, the brand of the mobile smart phone is a consideration in their buying decision. Because a reputable brand entails high standards of quality and after-sales service. Simultaneously, the Chinese prefer brands. Just like Chinese consumers seek out imported Mercedes-Benz and BMW automobiles, many Chinese consumers seek out Apple's latest mobile smart phones. Whenever Apple introduces new models of mobile smart phones, there is always news about Chinese people queuing up to purchase new Apple mobile smart phones; of course, their brand devotion is also high. When buyers consider purchasing a product on the Internet, they will not only look at the thorough product information (feature introduction, product image, and product video) given by the seller, but also at real consumer reviews and the brand. The online reputation of this product acts as a guide for determining whether or not to purchase it. As a result, the product's reputation is critical, and it is also one of the elements influencing consumers' buy intentions. 


\section{Objectives of the Research}

This section will begin by stating the analysis's overall purpose, which will be determined by the problem description provided in the preceding section. Following that, a summary of the specific objectives will be provided to discuss the report's purpose. The objectives are as follows:

R01: To investigate the relationship between social media marketing and brand loyalty.

RO2: To conduct an examination of the relationship between electronic word of mouth and brand loyalty.

RO3: To conduct research into the relationship between social media marketing and customers' purchasing intentions.

RO4: To examine the relationship between brand loyalty and purchasing intention among consumers.

RO5: To examine the relationship between electronic word of mouth and customer intention to purchase.

\section{Review of the Literature \\ Social Media}

Social media are interactive digitally mediated platforms that enable the development and exchange of information, ideas, career interests, and other kinds of expression through virtual communities and networks (Obar, Jonathan, and Wildman, 2015). In China, they mostly consist of social networking sites such as Weibo and WeChat, as well as blogs, forums, and podcasts. Social media has exploded with dizzying energy on the rich soil of the Internet. (2017) (Yan et al., 2016). The material it disseminates has developed into a significant source of content for Internet users. It has not only generated a series of hot topics in people's social lives, but also much more. Attract traditional media outlets to conduct follow-up.

\section{Social Media Marketing}

Social networking sites are gradually displacing traditional marketing channels as a means of achieving a variety of marketing objectives, ranging from brand awareness to inviting people to purchase (Batra and Keller, 2016). Consumer-generated (rather than consumer-distributed) content will significantly increase the reach of brand-generated messages on well-known platforms such as Facebook and Twitter (Napoli, 2019). However, even as brands increasingly enter social media conversations, the influence on customers remains distressingly low; only.1\% of followers view a typical company tweet (Sullivan, 2014), and are likely to be lost in the huge expanse of big data (Horst and Duboff, 2015). Businesses face a difficult problem in developing compelling marketing messaging with material that is less likely to be buried and that customers will share.

\section{Brand Loyalty}

Purchases made with a social purpose in mind Individualistic purchasing is intrinsically motivated and self-satisfying, whereas purposeful purchasing is motivated by a desire to satisfy others. The term "intention" immediately comes to mind (Hwang and Kim, 2016). Businesses will have a better understanding of their consumers' requirements and wishes and will be able to better match their expectations by observing and anticipating their behaviour, which will help them 
attract customers and achieve long-term goals (Shahedul, Md. and Md., 2021). Value can mean different things to different individuals; for some, it means getting the best deal possible, while for others, it means spending their money wisely. To foster loyalty, you must first understand what value means to your target audience and then try to give it at every stage of the customer journey. This could include insuring the product or providing customer service 24 hours a day. Prioritizing anything before determining its relevance to your audience is a waste of time, regardless of how your customer group views value (Guo and Jiang, 2016). Thus, it is critical for a brand to demonstrate its value in order to maintain consumers' loyalty to the brand.

\section{Purchase Intention}

Teng and Wang (2015) discovered a significant positive association between these two constructs in terms of the effect of customer trust on purchase intention in a study done in Taiwan. On the other side, Nuttavuthisit and Thgersen (2017) rebutted the idea of scheduled activities by incorporating trust into the structural model. Additionally, the findings indicate that confidence has a beneficial effect on consumption. Perceived worth is a fluid concept, and the literature is divided on its definition and characteristics. One of them is that perceived value needs the consumer to make a broad assessment of the utility of a commodity or service based on their expectations of what they will receive and pay for (Alzaydi et al., 2018). Consumer trust is defined as a belief, feeling, or expectation regarding the trade partner's loyalty as a result of his or her intent, honesty, or competency (Moorman, Zaltman, and Deshpandé, 1992).

\section{Theoretical Framework}

\section{Theory of Reasoned Actions (TRA)}

The TRA defines a person's behavioural intention as the intersection of two determinants: a personal element known as behavioural attitude and a person's sense of social pressures known as subjective norm. In other words, the primary determinant of a person's behaviour is deemed to be his or her intention.

\section{Conceptual Framework}
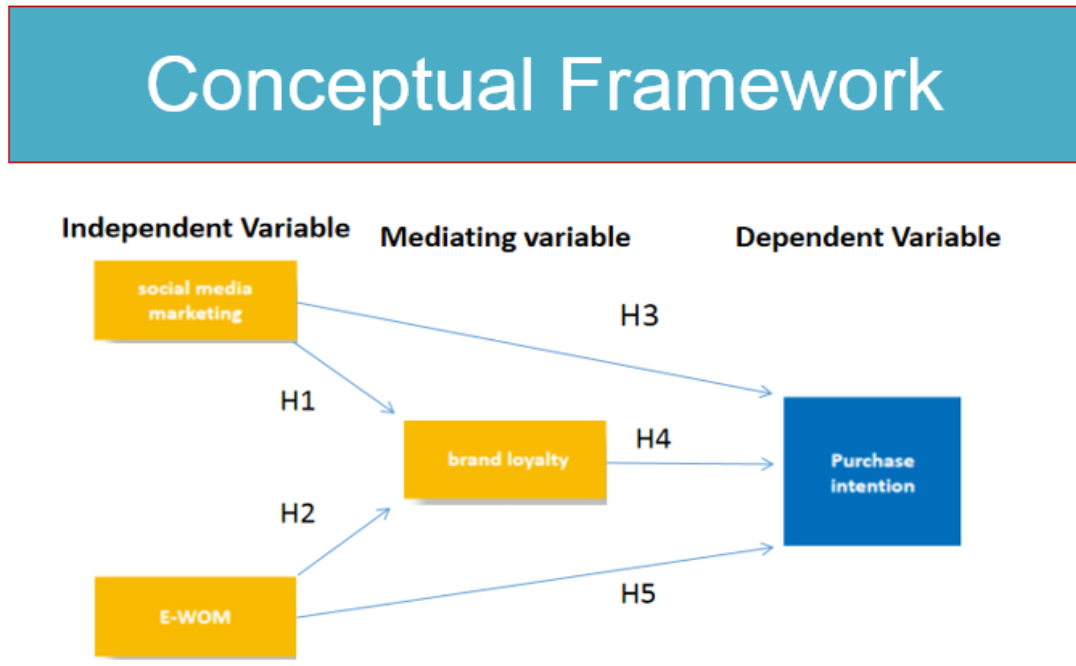
INTERNATIONAL JOURNAL OF ACADEMIC RESEARCH ECONOMICS AND MANAGEMENT SCIENCES Vol. 10 , No. 4, 2020, E-ISSN: 2226-3624 ㄷ 2020 HRMARS

\section{Developments in Hypotheses}

This section will present five hypotheses based on the relationships established in the preceding section's conceptual framework.

H1: Social media marketing will have a favourable influence on brand loyalty among customers. $\mathrm{H} 2$ : Electronic word of mouth will have a favourable influence on brand loyalty among consumers.

H3: Consumers' buying intentions will be positively influenced by social media marketing.

$\mathrm{H} 4$ : Consumers' buying intentions will be positively influenced by brand loyalty.

H5: Electronic word-of-mouth will have a beneficial influence on customers' purchasing intentions.

\section{Methodology of Research}

The research will take a positivist stance in this study, however objectivism will be utilised from an ontological standpoint. This was also consistent with the epistemological position that the research would be conducted via structured questionnaire data collecting and statistical software analysis. The approach taken in this work is quantitative analysis based on positivist philosophy and the deductive approach. As a result, this research is referred to as a structural approach, as the data collected will be statistically analysed using statistical analysis tools. Additionally, to obtain replies based on the theoretical application in response to the research objectives.

\section{Sampling and Population}

The study's methodology is based on nonprobability sampling. The sample approach used is convenience sampling. Comfort sampling is frequently employed since, in comparison to other methods, it is also quite straightforward to obtain (Saunders et al, 2012). Sampling convenience is effective in collecting a large number of results fast and affordably. This study will focus on respondents from Guangzhou, where the target demographic has access to social media sites.

Saunders et al. argued for and group within the sample using the handy rule of thumb of a minimum of 30 sample sizes. Although Hair et al (2010) recommended a 5:1 ratio, each independent variable consists of five observations. Hair et al. (2010), on the other hand, note that the best level of observation for each independent variable is between 15 and 20 observations.

As a result, a minimum of 150 sample sizes will be required for each of the three independent variables in this study, in accordance with (Saunders, Lewis, and Thornhill, 2012). When examining five or fewer constructs, a minimum of 100 sample sizes should be used, according to (Hair et al., 2010).

\section{Test of Reliability}

A reliability test on related dependent and independent variables is required to conduct and fulfil factor analysis. The term "reliability check" refers to the process of determining the internal correctness of measurements that give identical findings under identical conditions (Sekaran and 
Bougie, 2016). Cronbach's alpha values will be determined in this study using four variables and twenty items. Cronbach's alpha values utilised in this investigation are listed in the Table below.

Table 1: Cronbach's Alpha, Reliability Test

\begin{tabular}{|c|c|c|}
\hline \multicolumn{3}{|c|}{ Reliability Statistics } \\
\hline \multirow{4}{*}{$\begin{array}{l}\text { Cronbach's } \\
\text { Alpha }\end{array}$} & Cronbach's & \\
\hline & $\begin{array}{l}\text { Alpha Based } \\
\text { on }\end{array}$ & \\
\hline & Standardized & \\
\hline & Items & $\mathrm{N}$ of Items \\
\hline .887 & .892 & 20 \\
\hline
\end{tabular}

The Cronbach alpha value for all dependent and independent variables is 0.887 , as seen in the table above. This value means that all variables have excellent internal accuracy, indicating that all 20 things in this analysis have Cronbach's Alpha values above 0.7 , which are accurate and appropriate. As a result, this research can be continued. The Cronbach a values for each variable are mentioned in the table below.

Table 2: Cronbach's Alpha Values for each variable

\begin{tabular}{|l|l|l|}
\hline Component & $\begin{array}{l}\text { Cronbach's } \\
\text { Alpha }\end{array}$ & Items \\
\hline Social Media Marketing (SMM) & 0.706 & 5 \\
\hline Brand Loyalty (BL) & 0.768 & 5 \\
\hline Electronic Word of Mouth (eWOM) & 0.801 & 5 \\
\hline Purchase Intention (PI) & 0.858 & 5 \\
\hline
\end{tabular}

As illustrated in Table above, purchase intention has the greatest Cronbach's alpha value of 0.858, indicating the strongest internal consistency with the five questions, followed by electronic Word of Mouth (0.801), brand loyalty (0.768), and social media marketing (0.706). Cronbach's alpha readings for these variables are generally accurate, ranging from very good to excellent. Cronbach's coefficients are all greater than 0.5, indicating that the data is internally consistent and credible, ranging from 0.706 to 0.858 .

\section{Testing Hypotheses}

Multiple regression analysis and one-way ANOVA were employed in this study to examine the association between two or more dependent or independent variables, and logical approaches for analysis and statement were used (Yockey, 2011).

$\mathrm{H} 1$ and $\mathrm{H} 2$ hypotheses testing 
INTERNATIONAL JOURNAL OF ACADEMIC RESEARCH ECONOMICS AND MANAGEMENT SCIENCES

Vol. 10 , No. 4, 2020, E-ISSN: 2226-3624 ㄷ 2020 HRMARS

As described before, the hypothesis was developed in accordance with the research objectives. This section examined $\mathrm{H} 1$ and $\mathrm{H} 2$, where the dependent variable is brand loyalty.

$\mathrm{H} 1$ : Social media marketing will have a favourable effect on brand loyalty among customers.

$\mathrm{H} 2$ : Electronic word of mouth will have a favourable effect on brand loyalty among consumers.

Multiple regression analysis was utilised to measure the influence of independent variables on the dependent variable, purchase intention, including social media marketing, brand loyalty, and e-WOM.

Table 3: Model summary

\begin{tabular}{|c|c|c|c|c|}
\hline \multicolumn{5}{|c|}{ Model Summary } \\
\hline Model & $\mathrm{R}$ & R Square & $\begin{array}{l}\text { Adjusted } \quad \mathrm{R} \\
\text { Square }\end{array}$ & $\begin{array}{l}\text { Std. Error of } \\
\text { the Estimate }\end{array}$ \\
\hline 1 & $.739^{a}$ & .492 & .488 & .59489 \\
\hline
\end{tabular}

The $R$ value is 0.739 , which shows high strength of correlation between the independent variables and dependent variable. The $R^{2}$ value indicates how much of the total variation in the dependent variable, brand loyalty, can be explained by the independent variable, Social Media Marketing and eWOM. In this case, where $\mathrm{R}^{2}$ value is 0.492 , this means that $49.2 \%$ of the variation in the purchase intention can be explained by the independent variables as mentioned. The remaining $50.8 \%$ of the total variation in the purchased intention will be addressed by other variables and unknown factors which are not discussed in this study.

Table 4: ANOVA table

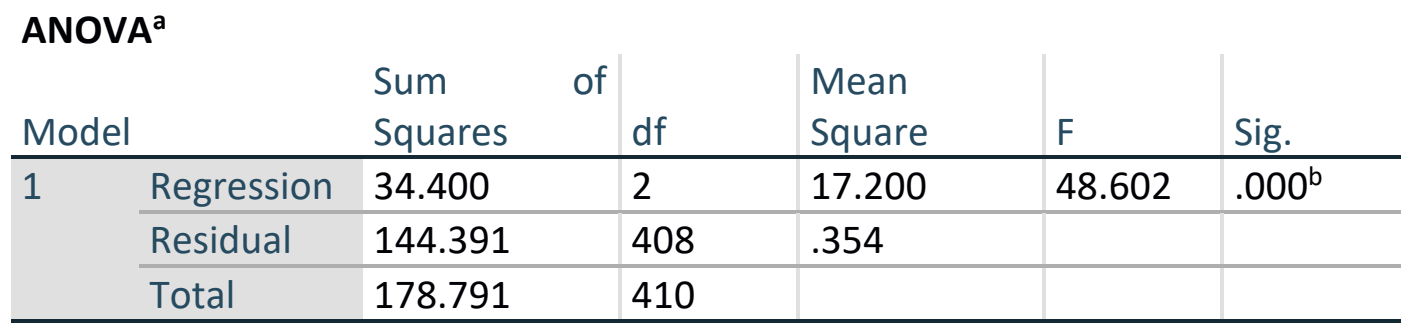

a. Dependent Variable: brand_loyalty

b. Predictors: (Constant), eWOMc, social_media_marketing

The ANOVA table checks whether the overall regression model is a good fit for the data. According to table, the $p$-value (Sig) is 0.000 , which is less than $\alpha=0.05$, this indicates that the model is valid and hence it has some predictability power among the independent variables and dependent variable. The multiple regression model with the two predictors produced $\mathrm{F}$ value of 
48.602 and $p$-value is significant. This indicates that the combination of the predictors significantly predicts brand loyalty.

Table 5: Table of coefficient for the multiple regression.

\section{Coefficients $^{\mathrm{a}}$}

\begin{tabular}{|c|c|c|c|c|c|c|}
\hline \multirow{2}{*}{\multicolumn{2}{|c|}{ Model }} & \multicolumn{2}{|c|}{$\begin{array}{l}\text { Unstandardized } \\
\text { Coefficients }\end{array}$} & \multirow{2}{*}{$\begin{array}{l}\text { Standardized } \\
\text { Coefficients } \\
\text { Beta } \\
\end{array}$} & \multirow[b]{2}{*}{$\mathrm{t}$} & \multirow[b]{2}{*}{ Sig. } \\
\hline & & $\mathrm{B}$ & Std. Error & & & \\
\hline \multirow[t]{3}{*}{1} & (Constant) & 1.806 & .180 & & 10.051 & .000 \\
\hline & $\begin{array}{l}\text { social_media_marketin } \\
\mathrm{g}\end{array}$ & .382 & .048 & .381 & 7.955 & .000 \\
\hline & eWOMc & .101 & .041 & .118 & 2.463 & .014 \\
\hline
\end{tabular}

a. Dependent Variable: brand_loyalty

According to Table above, the p-values (Sigs) for social media marketing and electronic word of mouth are 0.000 and 0.014 , respectively. Both of these $p$-values are less than 0.05 , indicating that these two variables have a statistically significant impact on brand loyalty. For the unstandardized coefficient, a one-unit increase (positive) in social media marketing results in a 0.382-unit increase in brand loyalty; whereas, a one-unit increase (positive) in eWOM results in a 0.101-unit increase in brand loyalty.

When we look at the standardised coefficient, we see that it is expressed in standard deviation units; this means that a one standard deviation change in social media marketing results in a 0.381 standard deviation rise in brand loyalty. The same holds true for eWOM, where an increase in eWOM results in a 0.118 standard deviation increase in purchase intention. This finding demonstrates that both social media marketing and electronic word of mouth have a major impact on brand loyalty.

As a result, the model's total equation is:

Brand loyalty $=1.806+0.382$ social media marketing $+0.101 \mathrm{eWOM}$

Analysis of Multiple Regression for $\mathrm{H} 3, \mathrm{H} 4$, and $\mathrm{H} 5$.

Multiple regression analysis was utilised to examine the impact of independent variables on the dependent variable, purchase intention, including social media marketing, brand loyalty, and eWOM. The following are the hypotheses:

H3: Social media marketing will have a large beneficial influence on customers' purchasing intentions.

H4: Consumers' purchase intentions will be significantly influenced by brand loyalty.

H5: Electronic word of mouth will have a large beneficial influence on customers' purchasing intentions. 
Table 6: Model summary

Model Summary
\begin{tabular}{l|l|l|l} 
Model R & R Square & $\begin{array}{l}\text { Adjusted } \\
\text { Square }\end{array}$ & $\begin{array}{l}\text { R } \\
\text { Std. Error of } \\
\text { the Estimate }\end{array}$ \\
\hline $1 \quad .739^{a}$ & .546 & .543 & .59543 \\
\hline a. Predictors: & (Constant), eWOMc, & brand_loyalty, \\
social_media_marketing \\
b. Dependent Variable: purchase_intention
\end{tabular}

The $R$ value represents the simple correlation and is 0.739 . The $R^{2}$ value indicates how much of the total variation in the dependent variable, Purchase Intention, can be explained by the independent variable, Social Media Marketing, eWOM and brand loyalty. In this case, where $\mathrm{R}^{2}$ value is 0.546 , this means that $54.6 \%$ of the variation in the purchase intention can be explained by the independent variables as mentioned. The remaining $45.4 \%$ of the total variation in the purchased intention will be addressed by other variables and unknown factors which are not discussed in this study.

Table 7: ANOVA table

ANOVA $^{a}$

\begin{tabular}{|c|c|c|c|c|c|c|}
\hline Model & & $\begin{array}{ll}\text { Sum } & \text { of } \\
\text { Squares }\end{array}$ & df & $\begin{array}{l}\text { Mean } \\
\text { Square }\end{array}$ & $\mathrm{F}$ & Sig. \\
\hline \multirow[t]{3}{*}{1} & Regression & 173.505 & 3 & 57.835 & 163.127 & $.000^{b}$ \\
\hline & Residual & 144.297 & 407 & .355 & & \\
\hline & Total & 317.802 & 410 & & & \\
\hline
\end{tabular}

a. Dependent Variable: purchase_intention

b. Predictors: (Constant), eWOMc, brand_loyalty, social_media_marketing

The ANOVA table checks whether the overall regression model is a good fit for the data. According to table 4.6, the p-value (Sig) is 0.000 , which is less than $\alpha=0.05$, this indicates that the model is valid and hence it has some predictability power among the independent variables and dependent variable. The multiple regression model with the two predictors produced $\mathrm{F}(3$, $407)=163.127$ and $p$-value is significant. This indicates that the combination of the predictors significantly predicts purchase intention. 
Table 8: Table of coefficient for the multiple regression.

\begin{tabular}{|c|c|c|c|c|c|c|}
\hline \multicolumn{7}{|c|}{ Coefficients $^{a}$} \\
\hline \multirow{2}{*}{\multicolumn{2}{|c|}{ Model }} & \multicolumn{2}{|c|}{$\begin{array}{l}\text { Unstandardized } \\
\text { Coefficients }\end{array}$} & \multirow{2}{*}{$\begin{array}{l}\text { Standardized } \\
\text { Coefficients } \\
\text { Beta } \\
\end{array}$} & \multirow[b]{2}{*}{$\mathrm{t}$} & \multirow[b]{2}{*}{ Sig. } \\
\hline & & $\mathrm{B}$ & Std. Error & & & \\
\hline \multirow[t]{4}{*}{1} & (Constant) & -.345 & .201 & & -1.717 & .087 \\
\hline & $\begin{array}{l}\text { social_media_marketin } \\
\mathrm{g}\end{array}$ & .079 & .052 & .059 & 1.535 & .125 \\
\hline & brand_loyalty & .380 & .050 & .285 & 7.665 & .000 \\
\hline & eWOMc & .661 & .041 & .580 & 15.998 & .000 \\
\hline
\end{tabular}

a. Dependent Variable: purchase_intention

From Table above, the p-value (Sig) for the brand loyalty and eWOM is less than 0.05, which indicates that these two variables are of statistical significance influence to the purchase intention. However, the $p$-value for social media marketing is 0.125 , which is greater than $\alpha=$ 0.05 , indicating that it has no statistical significant influence on purchase intention. Hence, the following section will only focus on brand loyalty and eWOM.

The unstandardized coefficient is needed because of different unit measured by the variables. Hence, in this case, every one unit positive change in brand loyalty will have 0.38 unit positive change in purchase intention. Same goes to eWOM, where one unit positive change in eWOM, it will positively impact the purchase intention by 0.661 . The standardized coefficient is measured in units of standard deviation, this means that a change in one standard deviation in brand loyalty will result in 0.285 standard deviation increase in purchase intention. Same goes to eWOM, where one standard deviation increase in eWOM will result in 0.041 standard deviation increase in purchase intention. This finding shows that, both brand loyalty and eWOM have significant influence on purchase intention.

Hence, the overall equation of the model is

Purchase intention $=-0.345+0.380$ brand loyalty +0.661 eWOM

\section{Hypotheses Result Summary}

According to multiple regression analysis and One-Way ANOVA the result indicated that four otu of five hypotheses are statistically significant and namely $\mathrm{H} 1, \mathrm{H} 2$ and $\mathrm{H} 4$ and $\mathrm{H} 5$ are supported. 
Table 9: Hypothesis Testing Result

\begin{tabular}{|l|l|}
\hline Hypothesis & Result \\
\hline $\begin{array}{l}\text { H1: Social media marketing will have positive influence on } \\
\text { consumers' brand loyalty. }\end{array}$ & Supported \\
\hline $\begin{array}{l}\text { H2: Electronic word of mouth will have positive influence on } \\
\text { consumers' brand loyalty. }\end{array}$ & Supported \\
\hline $\begin{array}{l}\text { H3: Social media marketing will have positive influence on } \\
\text { consumers' purchase intention. }\end{array}$ & Not supported \\
\hline $\begin{array}{l}\text { H4: Brand loyalty will have positive influence on consumers' } \\
\text { purchase intention. }\end{array}$ & Supported \\
\hline $\begin{array}{l}\text { H5: Electronic word of mouth will have positive influence on } \\
\text { consumers' purchase intention. }\end{array}$ & Supported \\
\hline
\end{tabular}

\section{Conclusion and Recommendations}

According to this study, social media marketing and electronic word of mouth have a considerable influence on brand loyalty. Additionally, the study demonstrated that brand loyalty and electronic word of mouth have a 95 percent confidence level effect on purchase intention.

To begin, scholars may refer to these research findings in order to do additional research. There are few studies on the factors that influence the shopping patterns of Guangzhou consumers. Additionally, it may aid in future research on Guangzhou consumers' purchasing behaviours, as well as crucial characteristics like as social media marketing, E-WOM, and brand loyalty. Finally, this research explores the elements that influence the purchasing decisions of Guangzhou consumers.

Additional research is required to determine the impact on customers. There is a significant amount of consumer research conducted, but not in Guangzhou. The outcomes of this study may serve as a springboard for additional research on the subject. The findings of this study aided the government in comprehending and forecasting consumer behaviour in Guangzhou. Additionally, it may aid in market forecasting and provide insight into how customers will react to unusual events and the market.

According to the findings, focusing on eWoM is the most important factor in determining purchase intent in the smartphone industry. Management of smartphone companies can use these findings to improve their marketing goals on a continuous basis especially the eWoM. In addition, management can conduct surveys or solicit feedback from existing customers to test this factor.

\section{References}

Alzaydi, Z. M., Al-Hajla, A., Nguyen, B., \& Jayawardhena, C. (2018). A review of service quality and service delivery: Towards a customer co-production and customer-integration approach, Business Process Management Journal, Vol. 24 No. 1, pp. 295-328.

https://doi.org/10.1108/BPMJ-09-2016-0185. 
Batra, R., \& Keller, K. L. (2016). Integrating Marketing Communications: New Findings, New Lessons, and New Ideas. Journal of Marketing, 80, 122 - 145.

Guo, X., \& Jiang, B. (2016). Signaling through Price and Quality to Consumers with Fairness Concerns. Journal of Marketing Research, 53(6), 9881000. https://doi.org/10.1509/jmr.15.0323.

Horst, Duboff, P., \& Duboff, R. (2015). Don't Let Big Data Bury Your Brand, Retrieved http://marketingland.com/facebook-twitter- impressions-90878.

Hwang, K., \& Kim, H. (2016). Are ethical consumers happy? Effects of ethical consumers' motivations based on empathy versus self-orientation on their happiness. Journal of Business Ethics, 1-20. doi: 10.1007/s10551-016-3236-1.

Mohamad, M., \& Dron, R. (2016). Electronic Word of mouth for mobile fitness application: an action case study. 10.13140/RG.2.1.3584.2645.

Napoli, P. (2009). Navigating Producer-Consumer Convergence: Media Policy Priorities in the Era of User Generated and Distributed Content. Communications \& Convergence Review. 1. 3243.

Nuttavuthisit, K., \& Thøgersen, J. (2017). The Importance of Consumer Trust for the Emergence of a Market for Green Products: The Case of Organic Food. Journal of Business Ethics. 140. 10.1007/s10551-015-2690-5.

Obar, J. A., \& Wildman, S. S. (2015). Social Media Definition and the governancechallenge: An introduction to the special issue. SSRN Electronic Journal. https://doi.org/10.2139/ssrn.2637879.

Saunders, M., Lewis, P., \& Thornhill, A. (2012). Research Methods for Business Students, 6th edition, Pearson education limited.

Sekaran, U., \& Bougie, R. (2016) Research Methods for Business: A Skill-Building Approach. 7th Edition, Wiley \& Sons, West Sussex.

Shahedul H, Md. A. I., \& Md. B-D. (2021). Crisis perception and consumption pattern during COVID-19: do demographic factors make differences?, Heliyon,Volume 7, Issue 5.

Sullivan, D. (2014). Just Like Facebook, Twitter's New Impression Stats Suggest Few Followers See What's Tweeted, Retrieved 2019-06-25 from https://martech.org/facebook-twitterimpressions/

Teng, C.-C., \& Wang, Y.-M. (2015). Decisional factors driving organic food consumption: Generation of consumer purchase intentions, British Food Journal, Vol. 117 No. 3, pp. 10661081. https://doi.org/10.1108/BFJ-12-2013-0361.

Wang, Y., \& Rodgers, S. (2010). Electronic word of mouth and consumer generated content: From concept to application. Handbook of Research on Digital Media and Advertising: User Generated Content Consumption, (January 2015), 212-231.

Yan, Y., Zha, D., Yan, A., Zhang, Q. (2016). Exploring the effect of individual differences on selfefficacy in getting information. Information Development, 32, 1097-1108.

Yockey, L. (2011). Testing the Hygiene Hypothesis: The Role of Bacteria in Promoting Atopy in a Mouse Model of Atopic Dermatitis. Spring,43. 